\title{
Experts blast US decision to back nuclear bunker-busters
}

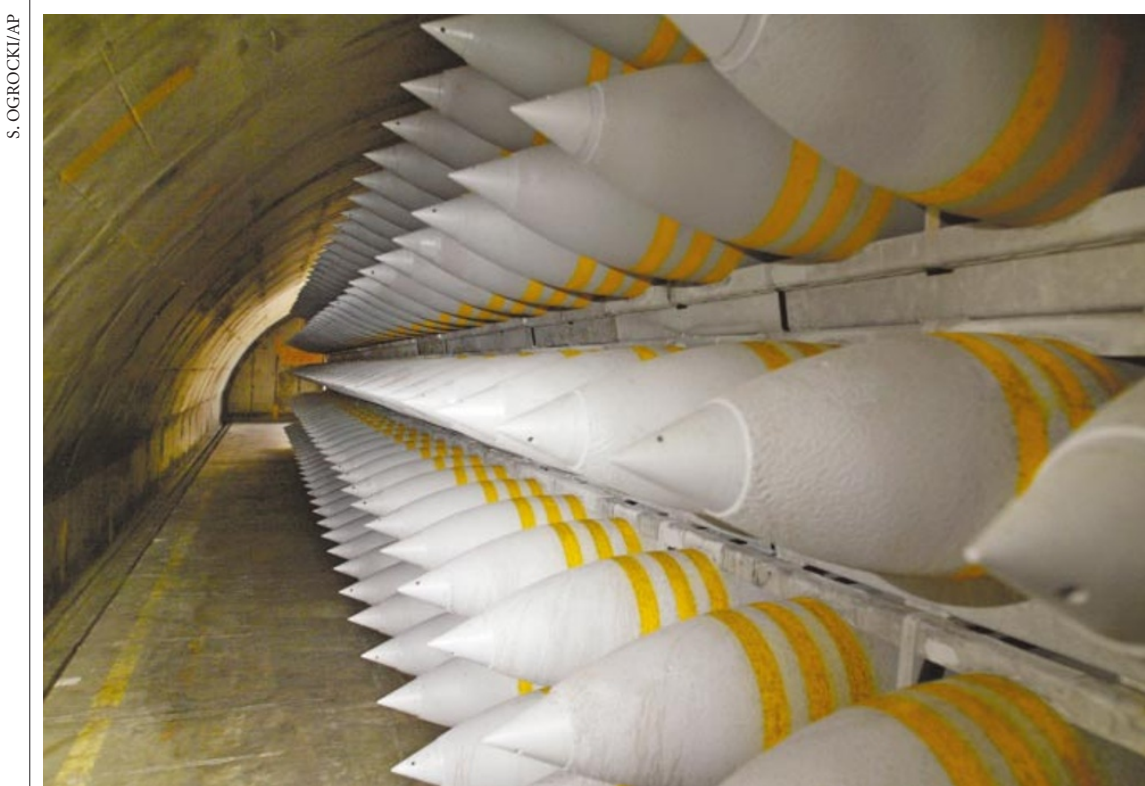

The United States plans to use nuclear warheads to beef up bunker-destroying bombs such as these.

Geoff Brumfiel, Washington

The US Congress has voted to plough $\$ 15$ million into developing Earth-penetrating nuclear weapons to destroy underground bunkers. But weapons experts have cast doubt on the scheme, arguing that this is an inappropriate use of nuclear technology.

The plan, which was proposed last year (see Nature 415, 945-946; 2002), aims to develop the weapons primarily to target hidden stores of biological or chemical weapons. According to the author of a new study, however, such agents may simply be dispersed by the weapons, and conventional weapons are better suited to the job.

President George W. Bush's administration welcomed last week's votes in both the House of Representatives and the Senate. General Richard Myers, Chairman of the Joint Chiefs of Staff, says that the radiation emitted by nuclear explosions could sterilize biological agents, and that the heat generated will destroy chemical weapons. Conventional weapons, he argues, are unsuitable as they are liable to spread such biological or chemical agents, creating a greater hazard.

But Robert Nelson, an astrophysicist and senior fellow at the Council on Foreign Relations, a think-tank based in New York, disagrees. In a paper shortly to appear in the journal Science and Global Security, he calculates the impact of an underground detonation of a nuclear device.

Nelson finds that rock or concrete surrounding a bomb would absorb heat and radiation, but would transmit the massive shockwave caused by the explosion. A nuclear device equivalent to 10,000 tonnes of TNT, for example, would create a crater 200 metres wide, but only material within 11 metres of the centre would be sterilized. Large amounts of material would be ejected from the centre of the blast, along with radioactive dust created in the explosion. Nelson suggests that it would be better to use conventional weapons to block the entrances and ventilation shafts of such bunkers until they could be secured by friendly forces.

Nelson admits that his analysis is basic, but argues that the results are clear-cut. Sidney Drell, deputy director emeritus of the Stanford Linear Accelerator Center in California and an architect of the US stockpile-stewardship programme, designed to maintain nuclear weapons without testing, agrees that the study is sound. He believes that the crater and sterilization area could be marginally larger than Nelson estimates, but echoes Nelson's argument that such a blast might only act to disperse chemical or biological agents.

Drell adds, however, that he is more concerned by the $\$ 6$ million allocated last week by the Congress for research into another new type of nuclear device - low-yield nuclear weapons known as mini-nukes. The United States has had a self-imposed ban on such weapons since 1993, but last week's vote marks an end to this ruling. Drell is worried that the move blurs the line between nuclear and conventional weapons, ultimately increasing the likelihood that nuclear weapons will be used in anger.
Deep-sea sub aims to get to the bottom of a muddy issue

Quirin Schiermeier, Munich

Europe's most advanced ocean-research robot set out for an 11-week Arctic expedition last week, its most ambitious to date. Researchers hope that Victor $\mathbf{6 0 0 0}$, one of the few craft that can reach depths of six kilometres, will provide insights into deep-sea corals and giant carbonate mounds - mud formations that can reach hundreds of metres in height.

"It's a fantastic tool," says cruise leader Michael Klages, a marine biologist at the Alfred Wegener Institute (AWI) of Polar and Marine Research in Bremerhaven, Germany. "This is the first time that we will be able to fully exploit its potential."

The $€ 15$-million (US\$17.8-million) craft, developed by IFREMER, France's national marine research agency, requires some 90 tonnes of winches, cables and navigation equipment, and a 3,000-volt generator. Data and control commands are relayed to and from the mother ship, the Polarstern, by a fibre-optic cable. Video cameras and robot arms can be used to examine organisms such as tube worms and sponges.

The first stop on the cruise, which is focused on areas of Europe's continental shelf, will be the Porcupine Seabight, a deepwater basin southwest of Ireland, where Victor 6000 will survey coral reefs and carbonate mounds. The Polarstern will then set off next month for the Håkon Mosby Mud Volcano, northwest of Norway.

The volcano releases methane-rich muddy fluids, which feed huge white mats of methane-dependent bacteria. Researchers plan to use Victor 6000 to probe the sediments and to survey the extent of the bacteria-covered slopes. Among other things, this should reveal how much methane escapes from the system and dissolves into the ocean.

The cruise will finally take the team to the AWI's 'House Garden', an established research area off Spitsbergen, an island group $650 \mathrm{~km}$ north of Norway. One study aims to deduce how benthic engineering - natural ploughing of the sediment by snails and crustaceans creates suitable habitats for bacteria and other microorganisms.

"The cruise is an exciting project", says Jon Copley, a deep-sea biologist at the Southampton Oceanography Centre, UK. "Whenever someone visits the deep ocean with new technology, they almost always advance our understanding of what goes on out there." www.polarstern-victor.de 